\begin{tabular}{|c|c|c|}
\hline Beitr. Ent. & Keltern & ISSN 0005-805X \\
\hline $\mathbf{6 0}(2010) 1$ & S. $229-242$ & 31.07 .2010 \\
\hline
\end{tabular}

\title{
A phylogenetic framework for the North American bumblebee species of the subgenus Bombus sensu stricto (Bombus affinis, B. franklini, B. moderatus, B. occidentalis \& B. terricola) based on mitochondrial DNA markers
}

\section{(Hymenoptera: Apidae: Bombus)}

With 4 figures and 3 tables

\author{
Andreas Bertsch, Martin Hrabé de Angelis and Gerhard K. H. Przemeck
}

\section{Zusammenfassung}

Königinnen der vier Taxa Bombus affinis, B. moderatus, B. occidentalis and B. terricola wurden an verschiedenen Orten quer durch Nordamerika gefangen. Zusätzlich wurden Männchen von B. franklini, B. occidentalis und B. terricola gesammelt. Mitochondriale Cytochrome Oxidase Untereinheit I (COI) von 25 Proben wurde sequenziert (Teilsequenzen 1005 bp Länge). Die Divergenz der Sequenzen zwischen den Taxa beträgt 30-50 Basen-Substitutionen und die Tamura-Nei Genetische Distanz 0.05-0.13, während innerhalb der Taxa die Divergenz nur 1 bis 2 Basen-Substitutionen beträgt und die Tamura-Nei Genetische Distanz 0.001-0.002. Da die COI Sequenzen keine Lücken aufweisen, können die einzelnen Nukleotide wie homologe Positionen verwendet werden. Jedes Taxon besitzt 8-20 eigene Substitutionen, die als diagnostische Positionen verwendet werden können, um das Taxon zu charakterisieren. Das Phylogramm zeigt drei klar getrennte Cluster: $B$. moderatus, konspezifisch mit der ostasiatischen $B$. albocinctus, das Artenpaar B. affinis - B. franklini locker verwandt mit der eurasiatischen B. lucorum, und das Artenpaar B. terricola - B. occidentalis ohne Beziehungen zu irgendwelchen Arten der Alten Welt.

\section{Summary}

Queens of Bombus affinis, B. moderatus, B. occidentalis and B. terricola were collected from different localities throughout North America. In addition, males of B. franklini, B. occidentalis and B. terricola were collected. Mitochondrial cytochrome oxidase subunit I (COI) was sequenced from 24 specimens (Partial sequences length $1005 \mathrm{bp}$ ). Interspecific sequence divergence was about 30-50 base substitutions and approximately $0.05-0.13$ in Tamura-Nei genetic distance, whereas the intraspecific sequence divergence was only 1-2 base substitutions and about $0.001-0.002$ in Tamura-Nei genetic distance. Because there are no gaps in the alignments of the COI sequences, single nucleotide sites can be used as positional homologies. Each taxon is characterised by about 8 to 20 substitutions, which are unique ("private") and can be used as diagnostic characters to define and identify this taxon. Three clusters in the topology of the phylogenetic tree were obtained: $B$. moderatus, which is con-specific to the East Asian B. albocinctus, a species pair B. affinis - B. franklini somehow related to the Eurasian $B$. lucorum and a species pair B. terricola - B. occidentalis without obvious connection to any Old World species. 


\section{Introduction}

With the recent publications of Pedersen (1996, 2002), Kawakita et al. (2004) and Cameron et al. (2007) we have, for the first time, a good general picture of the phylogenetic relationships of most bumblebee species. These molecular genetic investigations show that the long-lasting work on the taxonomy of bumblebee based on morphology has produced reliable results. At the level of subgenera there are only minor corrections necessary there are a few conflicting results which need further investigations, and there is much insight into the deeper nodes of phylogeny. However, at the terminal units of the branches many questions remain, and we need more specimens from a broad range of geographical localities to investigate the genetic polymorphism of the taxa.

Despite their size and conspicuous colouration, the identification of many species of the subgenus Bombus sensu stricto (syn. Terrestribombus) is often difficult because most species share a similar general appearance in colour and morphology, and there is a long-standing discussion about which taxa of the subgenus Bombus have species status, and which might be subspecies belonging to a broader species. In North America, five taxa in the subgenus Bombus sensu stricto are known: B. affinis (Cresson, 1863), B. franklini (Frison, 1921), B. moderatus (Cresson, 1863), B. occidentalis (Greene, 1858) and B. terricola (Kirby, 1837). In contrast to the five European species, which are more or less similar in colouration and difficult to separate by morphological characteristics, all five North American species of the subgenus Bombus sensu stricto are distinct in colouration with nearly no intraspecific variation. Only B. occidentalis shows some regional variability in colouration.

Because we expected a close relationship between the species investigated and consequently the 'bush-phylogenies' of recently diverged lineages we used mitochondrial DNA (mtDNA) as a marker. Because it has one-quarter of the effective population size of diploid nuclear genes, mtDNA is more likely to reflect genetic differentiation at recent internodes than nuclear genes (Moore 1995). MtDNA is maternally inherited and unlikely to recombine, thereby permitting the recovery of an unambiguous phylogenetic hypothesis for its evolution. It also evolves rapidly, with most of the changes occurring among closely related taxa nucleotide substitutions at silent sites. Because there are no gaps in the alignments of the COI sequences the alignment is unambiguous, and single nucleotide sites can be used as positional homologies (HILlis 1994). LEFÉBURE et al. (2006) investigated two mitochondrial genes, COI and 16S rRNA, and showed that for shallow taxonomic levels COI is the better marker. Simon et al. (1994) also concluded that protein-coding genes such as $\mathrm{COI}$ are more suitable than ribosomal genes for the phylogenetic analysis of close and intermediate levels of divergence. There is an ever-increasing number of theoretical discussions (BALlard and Whitlock 2004), and it might be useful to test the utility of COI in resolving shallow taxonomic levels in Bombus sensu stricto in practice.

To investigate the relationships of the North American subgenus Bombus sensu stricto we obtained partial sequences from the mitochondrial COI gene and addressed the following questions: (1) what is the nearest North American relative to the endemic B. franklini; (2) is Bombus moderatus really the North American B. lucorum; and (3) do B. terricola and B. occidentalis belong to the same species. 


\section{Materials and Methods}

\section{Bumblebee samples}

Table 1 shows the bumblebee samples used for DNA sequencing their identification codes and the localities of their origin with geographical coordinates. Figure 1 shows the sampling localities and their distribution across North America (with exception of the two samples $B$. franklini from southern Oregon). At the time of collection during 1997/1998, B. occidentalis in southern Oregon and B. terricola and B. affinis in Massachusetts were still common. After collection, bees were kept alive in a cool-box until they were deep-frozen. For molecular analysis, we examined one or two individuals from each of the localities for each taxon.

Tab. 1: List of Bombus samples $(\mathrm{FRA}=$ franklini, $\mathrm{AFF}=$ affinis, TER $=$ terricola, OCC $=$ occidentalis, $\mathrm{MOD}=$ moderatus, $\mathrm{LUC}=$ lucorum and $\mathrm{CRY}_{\mathrm{R}}=$ cryptarum $)$, used in the present analysis with identification codes, and collection locality information.

\begin{tabular}{|c|c|c|c|c|c|}
\hline & Locality & Country & State/Province & Coordinates & NN \\
\hline Fra-01 & Mt Ashland & USA & Oregon & $42^{\circ} 04.41^{\prime} \mathrm{N}, 122^{\circ} 43.41^{\prime} \mathrm{W}$ & $2050 \mathrm{~m}$ \\
\hline Fra-02 & Gold Hill & USA & Oregon & $42^{\circ} 25.81^{\prime} \mathrm{N}, 123^{\circ} 02.69^{\prime} \mathrm{W}$ & $330 \mathrm{~m}$ \\
\hline Aff-01 & Boston & USA & Massachusetts & $42^{\circ} 17.87^{\prime} \mathrm{N}, 71^{\circ} 07.35^{\prime} \mathrm{W}$ & $19 \mathrm{~m}$ \\
\hline Aff-02 & Marconi Beach & USA & Massachusetts & $41^{\circ} 53.45^{\prime} \mathrm{N}, 69^{\circ} 57.75^{\prime} \mathrm{W}$ & $8 \mathrm{~m}$ \\
\hline Aff-03 & Bridgewater & USA & Massachusetts & $41^{\circ} 59.05^{\prime} \mathrm{N}, 70^{\circ} 59.16^{\prime} \mathrm{W}$ & $30 \mathrm{~m}$ \\
\hline Aff-04 & New Hampton & USA & New Hampshire & $43^{\circ} 36.48^{\prime} \mathrm{N}, 71^{\circ} 39.26^{\prime} \mathrm{W}$ & $175 \mathrm{~m}$ \\
\hline Aff-05 & Adams County & USA & Wisconsin & $43^{\circ} 56.41^{\prime} \mathrm{N}, 89^{\circ} 50.88^{\prime} \mathrm{W}$ & $285 \mathrm{~m}$ \\
\hline Ter-01 & Winchester & USA & New Hampshire & $42^{\circ} 46.19^{\prime} \mathrm{N}, 72^{\circ} 22.21^{\prime} \mathrm{W}$ & $140 \mathrm{~m}$ \\
\hline Ter-02 & Brattleboro & USA & Vermont & $42^{\circ} 54.95^{\prime} \mathrm{N}, 72^{\circ} 31.67^{\prime} \mathrm{W}$ & $118 \mathrm{~m}$ \\
\hline Ter-03 & Weld & USA & Maine & $44^{\circ} 41.02^{\prime} \mathrm{N}, 70^{\circ} 21.45^{\prime} \mathrm{W}$ & $375 \mathrm{~m}$ \\
\hline Ter-04 & Sturgeon Lake & Canada & Alberta & $55^{\circ} 14.58^{\prime} \mathrm{N}, 117^{\circ} 24.11^{\prime} \mathrm{W}$ & $715 \mathrm{~m}$ \\
\hline Ter-05 & Emend Site & Canada & Alberta & $56^{\circ} 44.57^{\prime} \mathrm{N}, 118^{\circ} 24.23^{\prime} \mathrm{W}$ & $765 \mathrm{~m}$ \\
\hline Ter-06 & Smithers & Canada & British Columbia & $54^{\circ} 48.48^{\prime} \mathrm{N}, 127^{\circ} 04.51^{\prime} \mathrm{W}$ & $685 \mathrm{~m}$ \\
\hline Occ-01 & Mt Ashland & USA & Oregon & $42^{\circ} 04.41^{\prime} \mathrm{N}, 122^{\circ} 43.41^{\prime} \mathrm{W}$ & $2050 \mathrm{~m}$ \\
\hline Occ-02 & Eureka & USA & California & $40^{\circ} 46.41^{\prime} \mathrm{N}, 124^{\circ} 07.84^{\prime} \mathrm{W}$ & $5 \mathrm{~m}$ \\
\hline Occ-03 & Okotoks & Canada & Alberta & $50^{\circ} 43.25^{\prime} \mathrm{N}, 113^{\circ} 53.98^{\prime} \mathrm{W}$ & $1050 \mathrm{~m}$ \\
\hline Occ-04 & Dawson City & Canada & Yukon Territory & $64^{\circ} 02.57^{\prime} \mathrm{N}, 139^{\circ} 25.00^{\prime} \mathrm{W}$ & $320 \mathrm{~m}$ \\
\hline Occ-05 & Kitwanga & Canada & British Columbia & $55^{\circ} 06.13^{\prime} \mathrm{N}, 128^{\circ} 04.32^{\prime} \mathrm{W}$ & $175 \mathrm{~m}$ \\
\hline Occ-06 & Smithers & Canada & British Columbia & $54^{\circ} 48.48^{\prime} \mathrm{N}, 127^{\circ} 04.51^{\prime} \mathrm{W}$ & $685 \mathrm{~m}$ \\
\hline Mod-01 & Isabel Pass & USA & Alaska & $63^{\circ} 11.77^{\prime} \mathrm{N}, 145^{\circ} 33.64^{\prime} \mathrm{W}$ & $1095 \mathrm{~m}$ \\
\hline Mod-02 & Paxson & USA & Alaska & $63^{\circ} 0.94^{\prime} \mathrm{N}, 145^{\circ} 31.05^{\prime} \mathrm{W}$ & $950 \mathrm{~m}$ \\
\hline Mod-03 & Broad Pass & USA & Alaska & $63^{\circ} 19.31^{\prime} \mathrm{N}, 149^{\circ} 09.21^{\prime} \mathrm{W}$ & $725 \mathrm{~m}$ \\
\hline Mod-04 & Denali & USA & Alaska & $62^{\circ} 39.91^{\prime} \mathrm{N}, 150^{\circ} 20.42^{\prime} \mathrm{W}$ & $195 \mathrm{~m}$ \\
\hline Mod-05 & Ya-Ha-Tinda Ranch & Canada & Alberta & $51^{\circ} 44.57^{\prime} \mathrm{N}, 115^{\circ} 32.52^{\prime} \mathrm{W}$ & $1615 \mathrm{~m}$ \\
\hline Mod-06 & Sheep River & Canada & Alberta & $50^{\circ} 39.11^{\prime} \mathrm{N}, 114^{\circ} 21.85^{\prime} \mathrm{W}$ & $1314 \mathrm{~m}$ \\
\hline Luc-01 & Marcinkonys & Lithuania & Alytus County & $54^{\circ} 21.04^{\prime} \mathrm{N}, 24^{\circ} 25.46^{\prime} \mathrm{E}$ & $145 \mathrm{~m}$ \\
\hline Luc-02 & Col de Vars & France & Hautes Alpes & $44^{\circ} 32.25^{\prime} \mathrm{N}, 06^{\circ} 42.21^{\prime} \mathrm{E}$ & $2115 \mathrm{~m}$ \\
\hline Cry-01 & Marcinkonys & Lithuania & Alytus County & $54^{\circ} 21.04^{\prime} \mathrm{N}, 24^{\circ} 25.46^{\prime} \mathrm{E}$ & $145 \mathrm{~m}$ \\
\hline Cry-02 & Klaistow & Germany & Brandenburg & $52^{\circ} 17.89^{\prime} \mathrm{N}, 12^{\circ} 51.60^{\prime} \mathrm{E}$ & $50 \mathrm{~m}$ \\
\hline
\end{tabular}




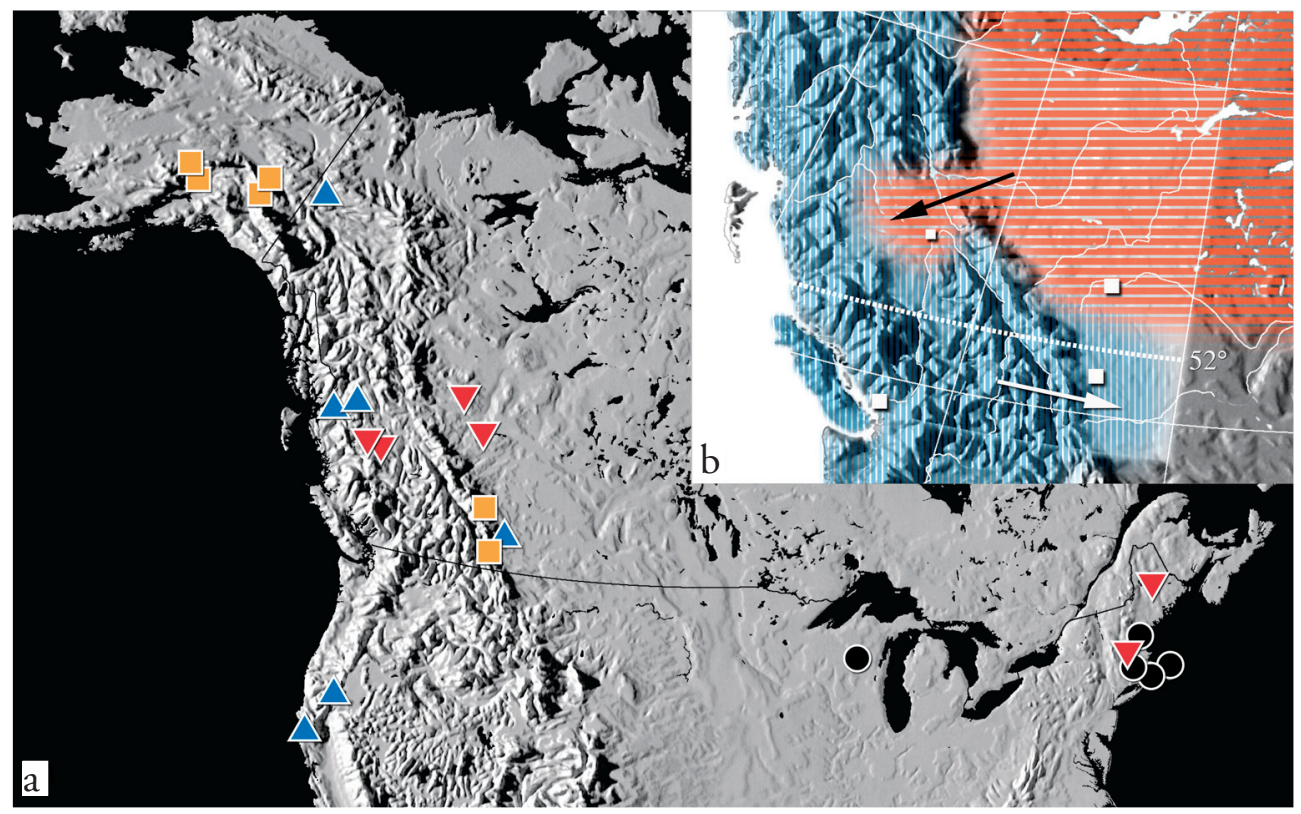

Fig. 1: (a) Sample localities for B. affinis (black circle), B. terricola (red triangle upside down), B. occidentalis (blue triangle) and $B$. moderatus (yellow square). (b) Distribution of $B$. terricola (red) in northern Alberta intruding into British Columbia (black arrow) and B. occidentalis (blue) in British Columbia intruding into southern Alberta (white arrow).

\section{Polymerase chain reaction (PCR) and DNA sequencing of mitochondrial COI}

Total DNA was extracted from legs using the QIAamp ${ }^{\circledR}$ DNA Mini Kit (Qiagen, Hilden, Germany) according to the manufacturer's specifications for tissue, and eluted in $150 \mu \mathrm{l}$ of highly purified water (Ampuwa ${ }^{\circledR}$, Fresenius Kabi, Bad Homburg, Germany). For sequence analysis we amplified overlapping fragments (in all $1027 \mathrm{bp}$ ) of mitochondrial COI using primers specifically designed for Bombus. BO-1-fwd (5' TAGGATCACCAGATATAGC 3') and BO-K-rev (5' GAGCTCAAACAATAAATCC 3') resulted in the amplification of a 609 bp fragment, whereas BO-5-fwd (5' AATGAAAGAGGTAAAAAAGAAAC 3') and BO-A-rev (5' ATGTTGAGGGAAAAATGTTAT 3') resulted in the amplification of a $510 \mathrm{bp}$ fragment. PCR amplifications were performed in $50 \mu \mathrm{l}$ reactions containing $100 \mathrm{ng}$ DNA template, $1.6 \mathrm{mM}$ $\mathrm{MgCl}_{2}, 75 \mathrm{mM}$ Tris- $\mathrm{HCl}(\mathrm{pH} 8.8), 20 \mathrm{mM}\left(\mathrm{NH}_{4}\right)_{2} \mathrm{SO}_{4}, 0.01 \%$ Tween 20, $0.2 \mathrm{mM}$ of each dNTP, 20 pmol of each primer and 1.5 units TaqDNA polymerase (Fermentas, St. Leon-Rot, Germany). Conditions for PCR amplifications were initial denaturation for $5 \mathrm{~min}$ at $94^{\circ} \mathrm{C}, 40$ cycles of $45 \mathrm{~s}$ denaturation at $9^{\circ} \mathrm{C}, 1 \mathrm{~min}$ annealing at $46^{\circ} \mathrm{C}, 3$ min elongation at $61^{\circ} \mathrm{C}$ (for $\mathrm{BO}-1$-fwd and $\mathrm{BO}-\mathrm{K}$-rev) or $63^{\circ} \mathrm{C}$ (for BO-5-fwd and BO-AA-rev), and final extension for $7 \mathrm{~min} .10 \mu \mathrm{l}$ of each reaction was checked on a $1 \%$ agarose gel. PCR products were purified using AMPure ${ }^{\oplus}$ PCR Purification Kit (Agencourt, Beverly, MA, USA). Sequencing reactions were performed using ABI BigDye Terminator version 3.1 chemistry (Applied Biosystems, Foster City, CA, USA) according to manufacturer's instructions and then analysed on an ABI 3100 sequencer (Applied Biosystems). Sequences were aligned manually using ClustalX. No gaps or poorly aligned regions occurred in the alignment, but missing characteristics were trimmed from the ends of the alignment to produce an equal sequence length of 1005 bp for all individuals (encoding 335 amino acids). For calculating the genetic distances the alignment was cut to a length of $846 \mathrm{bp}$, the length of 
the sequence of $B$. franklini available at GenBank (FRA-01 = AY694097). Individual alignments were aligned against the complete COI gene sequence of Bombus ignitus (GenBank Accession No. DQ870926; CHA et al. 2007) between positions 262 and 1267.

\section{Analysis of sequence divergence of mitochondrial COI}

The absolute numbers of substitutions were counted based on a pairwise comparison of COI sequences. The analysis for the sequences investigated was performed using the maximum composite likelihood method of Mega 4.0 (Tamura et al. 2007, Kumar et al. 2008), a program distributed by K. Tamura, J. Dudley, M. Nei and S. Kumar. Because the distribution of nucleotides in the COI of Hymenoptera is known to be heterogeneous, with a strong $\mathrm{A}+\mathrm{T}$ bias, we selected the Tamura-Nei (TN) model of base substitution (TAMURA and Nei 1993), which corrects this bias in its assumption of sequence evolution. The nucleotide frequencies and the parameters necessary for this model were estimated from the sequence data, and TN genetic distances were calculated. The best maximum likelihood model was selected using the jModelTest (POSADA 2008). The tree topology was inferred by a maximum likelihood tree based on the general time-reversible model (GTR plus gamma) calculated by Bayesian analysis (HuELSENBECK and RonQuist 2001) using MrBayes, a program distributed by J. P. Huelsenbeck and F. Ronquist. Tree topology was also calculated as a Minimum Evolution tree (ME) with bootstrap sampling, using Mega 4.0 (TAMURA et al. 2007). Geneious Pro 4.5 (Biomatters Ltd.) was used to analyse the alignment and detect diagnostic positions, and the GreenButton plugin (InterGrid) was used to do the time consuming MrBayes calculations on a supercomputer cluster. The nucleotide changes along the branches of cladograms were examined with MacClade 3.04. The COI sequence data of B. soroeensis (GenBank accession No. AY181159; Pedersen 2002) were used as an outgroup.

\section{Results}

\section{Nucleotide frequencies and substitution parameters}

The aligned data matrix of 1005 bp length of 25 sequences of the five North American specimens included 893 invariant and 112 variable sites. Of these positions, 12 were parsimony uninformative (noise) and 100 parsimony informative (signal). However, differences in this pattern were evident in the codon positions. The first positions comprised 15 informative positions; in third position 85 positions were informative. From the seven replacement sites six were in the first position and one in the third position. All 93 other informative variant sites were silent positions. Table 2 gives the pattern of nucleotide substitutions estimated from the data with the maximum Tab. 2: Maximum Composite Likelihood Estimate of the Pattern of Nucleotide Substitution. The transition/ transversion rate ratios are $\mathrm{k}_{1}=10.39$ (purines) and $\mathrm{k}_{2}=11.79$ (pyramidines), the overall transition/transversion bias is $\mathrm{R}=3.044$.

\begin{tabular}{|c|c|c|c|c|}
\hline & A & T & C & G \\
\hline A & - & 3.2 & 0.97 & $\mathbf{9 . 5 1}$ \\
\hline T & 2.5 & - & 11.48 & 0.92 \\
\hline C & 2.5 & 37.78 & - & 0.92 \\
\hline G & 26.03 & 3.2 & 0.97 & - \\
\hline
\end{tabular}
composite likelihood model (MEGA). The nucleotide frequencies were 33.6 (A), $42.1(\mathrm{~T}), 12.3(\mathrm{C})$ and $12.0(\mathrm{G})$, which proves the known strong $\mathrm{A}+\mathrm{T}$ bias typical for sequences of Hymenoptera.

\section{COI sequence divergence between and within species}

Because one of the sequences of $B$. franklini (FrA-01 = AY694097) was shorter we used 846 bp sequences in an analysis of sequence divergence among the five North American taxa. Table 3 
presents the matrix of evolutionary distance estimated by the TN model and the p-distances within and between the five North American taxa investigated. For comparison and discussion Genbank Sequences of the Russian Far East species B. albocinctus and sequences of the European species, B. cryptarum (CRY-01 and CRY-02) and B. lucorum (LuC-01 and LuC-02) were included in the analysis. The intraspecific genetic variability was low for all taxa (1-2 nucleotides, TN distance $0.001-0.002)$. By contrast, the interspecific genetic variability was approximately one order of magnitude larger (25-54 nucleotides, TN distance 0.038-0.070) for the North American taxa. The genetic distance between the North American B. moderatus and the Russian Far East $B$. albocinctus was exceptionally low with 0.004 , meaning both taxa must be conspecific.

Tab. 3: Mean genetic distance within and between taxa. Diagonal and lower left: TN model, rates among sites gamma distributed. Upper right: p-distance.

\begin{tabular}{|l|l|l|l|l|l|l|l|l|}
\hline & Aff & Occ & Ter & Mod & Fra & Alb & Luc & Cry \\
\hline affinis & $\mathbf{0 . 0 0 2}$ & 0.062 & 0.063 & 0.058 & 0.043 & 0.057 & 0.045 & 0.056 \\
\hline occidentalis & 0.068 & $\mathbf{0 . 0 0 1}$ & 0.036 & 0.041 & 0.053 & 0.039 & 0.046 & 0.043 \\
\hline terricola & 0.070 & 0.038 & $\mathbf{0 . 0 0 2}$ & 0.051 & 0.046 & 0.049 & 0.046 & 0.046 \\
\hline moderatus & 0.064 & 0.044 & 0.056 & $\mathbf{0 . 0 0 1}$ & 0.048 & 0.004 & 0.040 & 0.020 \\
\hline franklini & 0.046 & 0.059 & 0.051 & 0.053 & $\mathbf{0 . 0 0 1}$ & 0.047 & 0.038 & 0.049 \\
\hline & & & & & & & & \\
\hline albocinctus & 0.062 & 0.043 & 0.054 & 0.004 & 0.051 & $\mathbf{0 . 0 0 1}$ & 0.039 & 0.016 \\
\hline lucorum & 0.049 & 0.050 & 0.050 & 0.042 & 0.041 & 0.041 & $\mathbf{0 . 0 0 1}$ & 0.040 \\
\hline cryptarum & 0.062 & 0.048 & 0.051 & 0.021 & 0.054 & 0.017 & 0.043 & $\mathbf{0 . 0 0 0}$ \\
\hline
\end{tabular}

\section{Tree building by maximum likelihood models}

The maximum likelihood tree (Fig. 2) generated using the Bayesian MCMC (Markov chain Monte Carlo) analysis with 1005 bp full length sequences was based on the GTR of base substitution, gamma distribution and 5000000 generations to achieve stationary sampling every 10 generations and a "burn-in" every 5000 generations. For comparison, GenBank data of the Far East taxon B. albocinctus and the European taxa B. cryptarum and B. lucorum were included. The taxa formed three distinct clusters: cluster $\alpha$ with $B$. affinis and B. franklini and a weak connection with the European species $B$. lucorum, cluster $\beta$ with $B$. occidentalis and $B$. terricola and cluster $\gamma$ with $B$. moderatus and the Eurasiatic taxa $B$. albocinctus and $B$. cryptarum. Because the support for the branch connecting (B. occidentalis \& B. terricola) and (B. moderatus, B. albocinctus $\&$ B. cryptarum) has only a 0.67 probability, these two branches are also probably completely separate. However, the data are robust irrespective of the model used.

\section{Tree building by diagnostic characters}

Because there are no gaps in the alignments of the COI sequences, single nucleotide sites can be used as positional homologies (Hillis 1994). The alignment file (Fig. 3) shows clearly that each taxon is characterised by $9-25$ substitutions, which are unique ("private") and can be used as diagnostic characters to define and identify this taxon. In MacClade, the changes at the nodes and the diagnostic characters at the last branch of the terminal units can be investigated in detail, and a tree with the classical tools for morphological characteristics can be built (Fig. 4). The number of diagnostic positions in $B$. albocinctus $(=1)$ and $B$. moderatus $(=3)$ is exceptionally low, whereas both taxa share 14 diagnostic positions, a strong reference that both taxa must be conspecific. With the large number of diagnostic characteristics available it is normal that not all of these changes are unambiguous, but each of the five North American taxa is characterised by about 8-12 unambiguous diagnostic characters. 


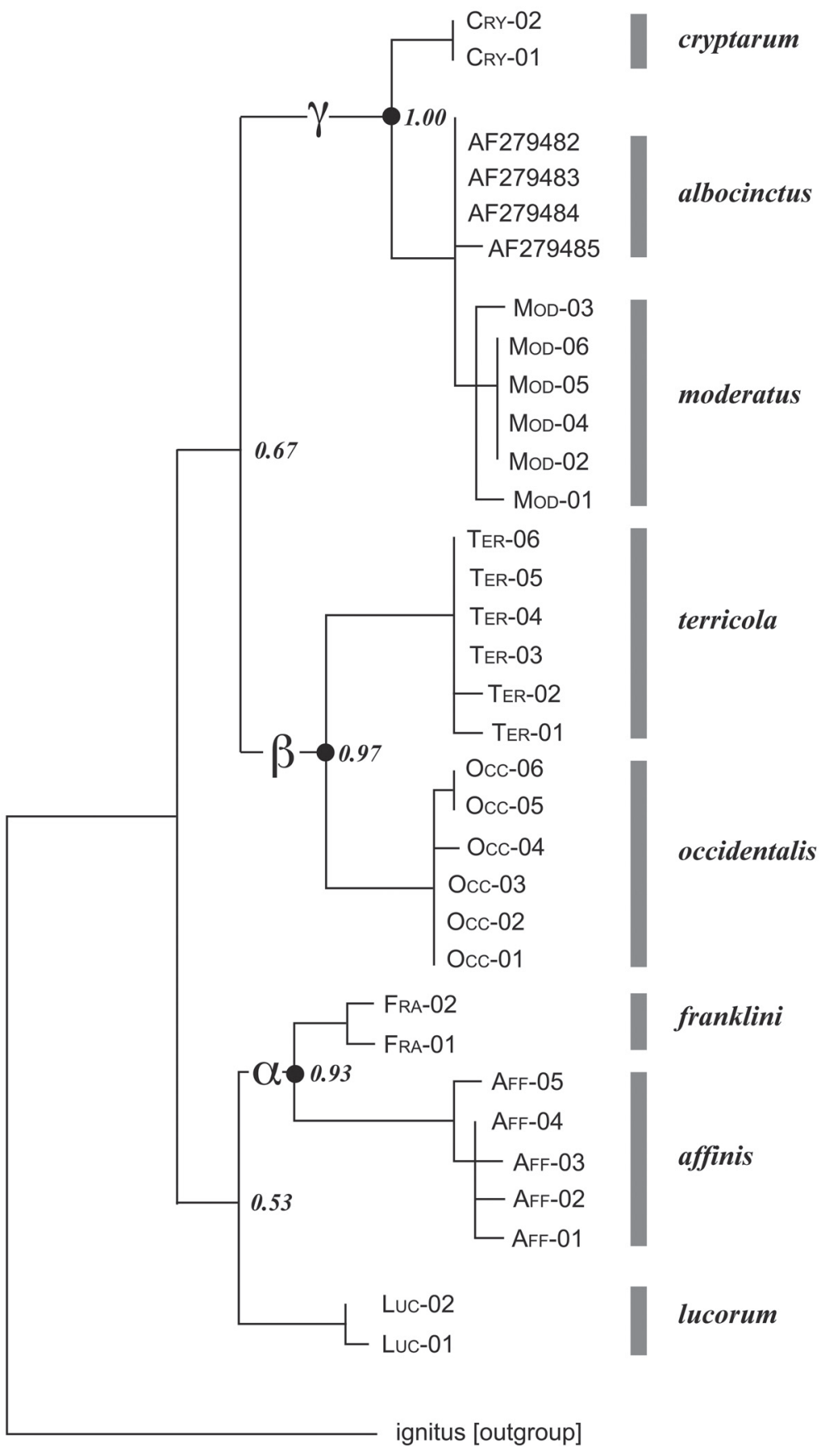

Fig. 2: Tree topology calculated as maximum likelihood tree using the Bayesian MCMC analysis with the GTR model of base substitutions, gamma distribution and 5000000 generations. 


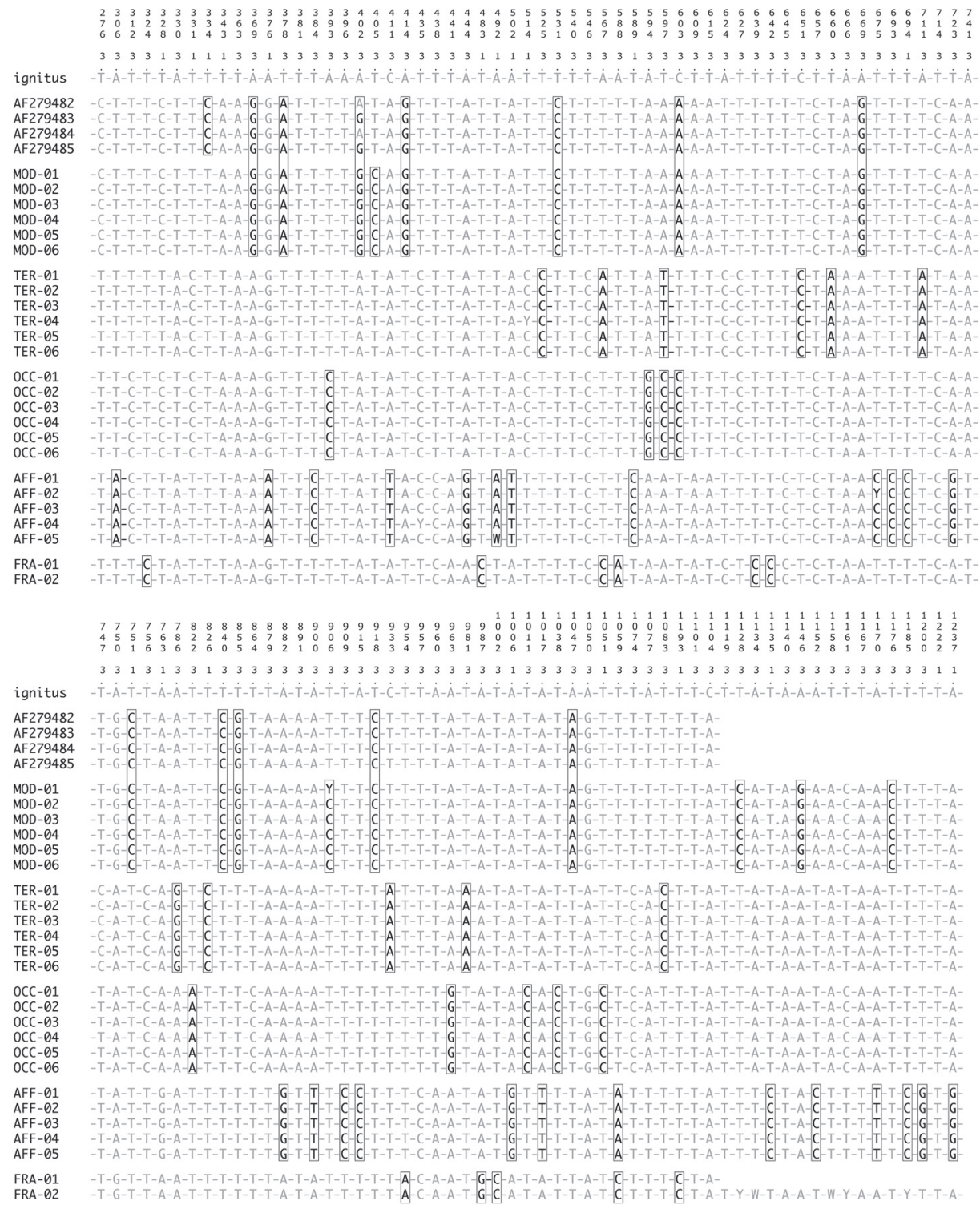

Fig. 3: Alignment of all variable (parsimonious informative) positions with uninformative positions deleted $(-)$, and with a pointer for position number (numbered for total COI) and codon position. Diagnostic (= private) positions for each taxon marked with a box. 


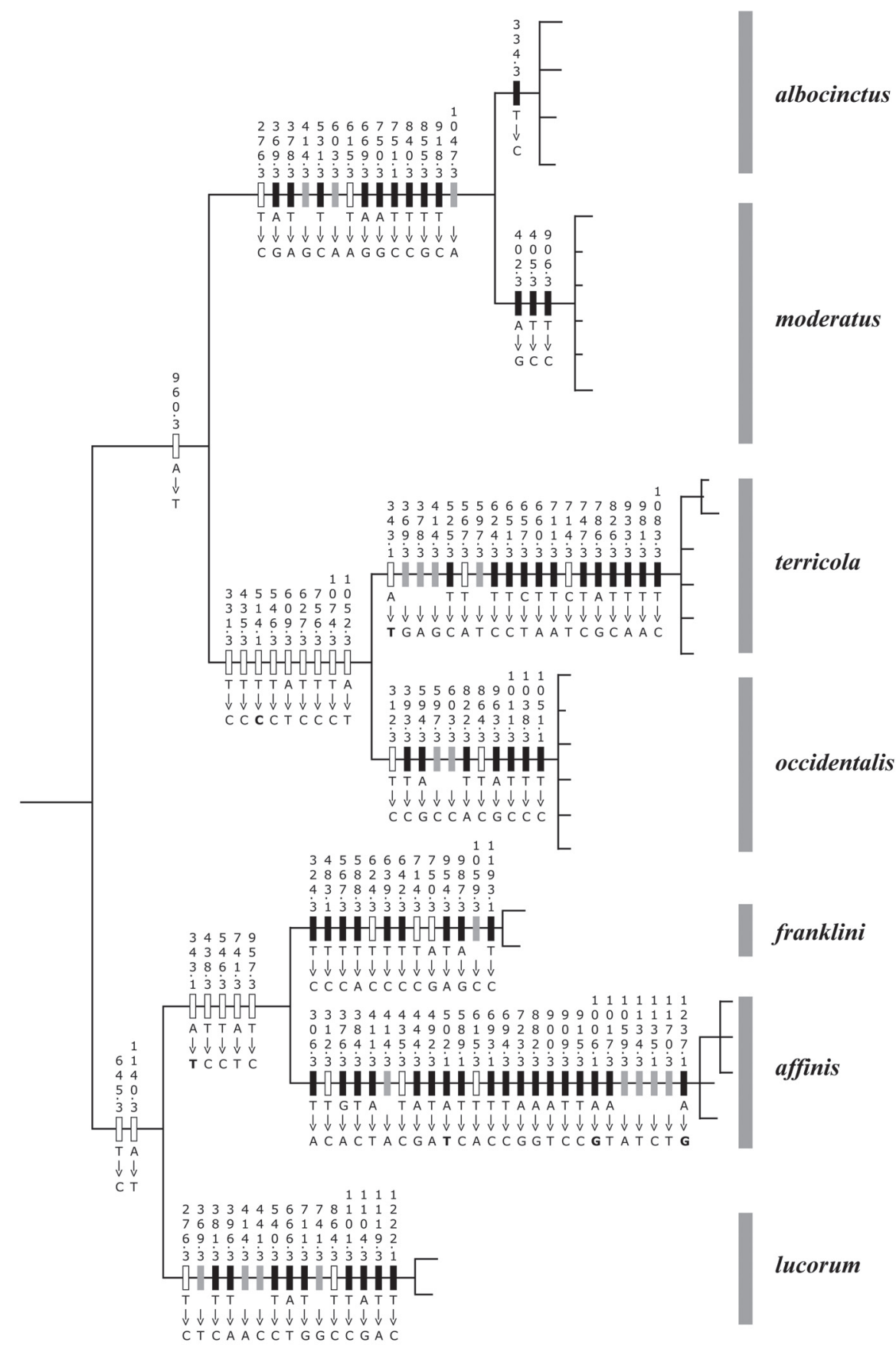

Fig. 4: Observed diagnostic characteristic changes with position numbers mapped onto the maximum likelihood tree. Black box $=$ unambiguous diagnostic character change, grey box $=$ ambiguous diagnostic character change and white box = unambiguous character change. 


\section{Discussion}

\section{Which North American species is genetically nearest to the endemic B. franklini?}

$B$. franklini, the taxon of the subgenus Bombus sensu stricto with the smallest range of distribution, was included in B. occidentalis by Milliron (1971), most probably based on a statement of STEPHen (1957, p. 79), that " both sexes of this species are similar to B. occidentalis ssp. occidentalis and often separation is difficult". By contrast, THORP et al. (1983) collected B. franklini at several localities sympatrically with $B$. occidentalis and found no intergrades between both taxa. Plowright and STEPHen (1980) place B. franklini separate from all other species of this subgenus (as result of a multivariate analysis of wing venation parameters) and conclude that "the origin of $B$. franklini is mysterious". By gel electrophoretic analysis of isoenzymes, ScHoll et al. (1992) showed that $B$. franklini is clearly separate from $B$. occidentalis. The mtDNA marker confirms the distance between $B$. franklini and $B$. occidentalis, and our data show that $B$. franklini is closely related to $B$. affinis. The mtDNA marker also indicates a weak relationship between both North American taxa and the European taxon B. lucorum. This relationship of B. lucorum, B. affinis and $B$. franklini is confirmed by the sequencing results of a nuclear gene (CAMERON et. al., 2007; supplementary material, Figure arginine kinase). But in some simulation models (most parsimonious tree with bootstrap values) the support probability for the node connecting B. lucorum with $B$. affinis-franklini is very low, and thereby this relationship cannot be very close. It would be interesting to investigate this possible phylogenetic connection by studying the biology and ecology of $B$. franklini and $B$. affinis in greater detail, but this might be difficult to accomplish because both taxa show a heavy decline and are most probably extinct (THORP 2005; Bryson and Haney 2006; Colla and Packer 2008).

\section{Is Bombus moderatus really the North American B. lucorum?}

By investigations of marker isoenzymes Scholl et al. (1990) showed that B. moderatus is very close to the European taxon $B$. cryptarum, and their phylogram shows clearly that both taxa (B. moderatus and B. cryptarum) are very separate from the European B. lucorum. The molecular marker COI confirms this result. The difference of the species pair B. cryptarum - B. moderatus is 21 nucleotides $(=0.021 \mathrm{TN}$ genetic distance $)$ compared with 40 nucleotides $(=0.040 \mathrm{TN}$ genetic distance) of the species pair $B$. moderatus $-B$. lucorum. The intraspecific difference is $1-3$ nucleotides (0.01-0.03 TN genetic distance). The lumping of $B$. moderatus and B. cryptarum into the species $B$. lucorum implies a high intraspecific genetic variability and also a large variability in species recognition signals, which is by no means compatible with the facts available.

At the beginning of the last century the European B. terrestris and B. lucorum were treated as one species, and it took a long time until their separation was generally accepted. KRÜGER separated the taxon B. latostriatus (KRÜGER, 1939) from B. lucorum, B. latostriatus was later synonymised with B. magnus (Vogt, 1911) by KrÜGer (1954). Rasmont (1984) surveyed the European part of the subgenus Bombus and resolved B. lucorum into three morphologically separate species B. lucorum, B. magnus and B. cryptarum, a view confirmed by investigations of the male labial glands (BERTSCH 1997) and mtDNA markers (Bertsch et al. 2005). Scholl and Oвrecht (1983) coined the term Bombus-lucorum complex to point out that we have to handle a complex of species difficult to separate by morphological characteristics. Within this complex of species, B. lucorum is a taxon well defined by morphology, colouration, labial gland secretions and DNA markers; there is no evidence available that $B$. lucorum is a species with high intraspecific variability. From Scotland to Yakutsia and the Transbaikal (distance $6500 \mathrm{~km}$ ) B. lucorum is genetically identical (1-3 nucleotides, 0.01-0.03 TN distance) and has identical species recognition signals (BERTSCH et al. 
unpublished results of male labial gland secretions). The lumping of $B$. lucorum with $B$. moderatus (Milliron 1971; Poole 1996; Williams 1998; Thorp and Shepherd 2005) cannot be correct because then $B$. franklini and $B$. affinis, which are genetically closer to $B$. lucorum than $B$. moderatus, must also be lumped into this "species in the broadest sense" (Williams, 2009).

B. moderatus is a clearly defined taxon, characterised by morphology and DNA markers. Mainly distributed in Alaska/USA (Franklin 1913 "confined to Alaska"), Yukon Territory, Northwest Territories and Banff/Alberta in Canada (Milliron 1971) with few additional records from Alberta (Scholl et al. 1990). The species is now expanding within Alberta/Canada (R. Cartar, by correspondence). Rasmont (1984 p.155) refers to a female specimen B. cryptarum from the Russian Far East (Primorsky Kray; Prohrovka near Vladivostok) and females from Sachalin (RAsmont et al. 1986 p. 678), which morphologically look very much like B. cryptarum. Tanaka, Ito and Inoue submitted to GenBank 4 unpublished sequences as B. cryptarum from the Russian Far East (from Magadan AF279485, Kamchatka AF279482 and the North Kuril Islands AF279483, AF279484), which belong to the widely distributed East Asian taxon B. albocinctus (M. Ito, by correspondence). These sequences from the Russian Far East are nearly identical to the $B$. moderatus sequences from Alaska (with a TN genetic distance of 0.004 ; Table 2); $B$. albocinctus and B. moderatus are conspecific and closely related to the European B. cryptarum. Further investigations are needed to close the gap between North America and Europe and reveal which Asian taxa are available to link the North American B. moderatus with the European B. cryptarum.

\section{Are B. terricola and B. occidentalis conspecific?}

B. terricola and B. occidentalis are a good example of two taxa that can be easily separated by their colouration, but show no other obvious morphological differences. B. terricola has the centre of distribution east of the Rocky Mountains and B. occidentalis west of the Rocky Mountains, with both taxa sharing only a small zone of contact in southern Alberta and British Columbia. They seem to be a classic example of closely related taxa with parapatric distribution, which are normally treated as "geographical" subspecies. But a closer look at the contact zone in southern Alberta and northern British Columbia (Fig. 1b) reveals ecological differences, with B. occidentalis a species of the "forest transition zone" (Munroe 1956) mainly distributed south of the 52nd parallel in British Columbia (Buckell 1951) and crossing the Rocky Mountains into Alberta (Hoвbs 1968), and B. terricola as a species of the "boreal forest zone" (Munroe 1956) mainly north of the 52nd parallel in Alberta (Новвs 1968) and crossing the Rocky Mountains into British Columbia (Buckell 1951). The genetic difference of about 30 nucleotides between $B$. terricola and B. occidentalis is much larger (one order of magnitude) than expected from within one species, and our results from COI are supported by the nuclear markers used by CAMERON et al. (2007). The difference between B. terricola-B. occidentalis in arginine kinase is five nucleotides, and four nucleotides in 16S RNA. Taxa are treated as conspecific by CAmeron et al. (2007, p. 179) if they differ by only 1-2 nucleotides (equivalent to $0.03-0.05 \%$ sequence divergence). $B$. terricola and B. occidentalis are obviously genetically separated (specimens Ter-06 and Occ-06 have been collected feeding simultaneously at a large patch of Cirsium near Smithers, British Columbia/Canada) and, therefore, fulfil the criteria of good biological species. Only a careful study of females and males of these taxa in their zone of contact in British Columbia and southern Alberta will help to further clarify the situation. According to FrankLIN (1912, p. 276), " $B$. terricola has its closest ally in the subspecies nigroscutatus of the species occidentalis. It differs from that form in always having the second dorsal abdominal segment entirely covered with yellow pile". B. occidentalis ssp. nigroscutatus now extinct (Thorp and Shepherd 2005) was distributed in coastal California (STEPHen 1957 Map. 9; Thorp et al. 1983); it is not a form of the contact zone of both taxa, from where neither Buckell (1951) nor Hoвbs (1968) reported any 
"intergrading" of females or males as described by WiLliams (2009) for workers of these taxa. This is confirmed by STEPHEN (1957, p. 82), who states that "B. terricola is one of the most colour stable species in western America and shows little or no variation throughout its range".

\section{Acknowledgments}

Prof. R. Thorp (Davis/California) gave valuable advice and helped to collect the male B. franklini (FrA-01), Prof. J. R. J. van Asperen de Boer (Amsterdam/Netherlands) supplied the specimen B. franklini (FrA-02) from his collection. Prof. B. Heinrich (Burlington/Vermont) collected the specimen B. terricola (Ter-03) from Maine/USA, Prof. A. Scholl (Bern/Switzerland) collected the specimen B. moderatus (Mod-05) from Alberta/Canada, Prof. R. Cartar (Calgary/Canada) supplied the specimens B. moderatus (MoD-06) and B. terricola (Ter-05) from Alberta/Canada and helped with discussions. Dr. M. Ito (Sapporo) confirmed the identity of the Far East GenBank sequences B. cryptarum with B. albocinctus. We would like to thank them all for their valuable help.

\section{References}

BALlaRd, J. W. O. \& Whitlock, M. C. 2004: The incomplete natural history of mitochondria. - Molecular Ecology 13: 729-744.

Bertsch, A.1997: Wieviele Arten dere Untergattung Terrestribombus (Hymenotpera, Apidae) gibt es in Nordhessen; die Abgrenzung von B. cryptarum und B. lucorum mittels männlicher Labialdrüsensektrete und morphologischer Merkmale. - Marburger Entomologische Publikationen 2: 1-28.

Bertsch, A.; Schweer, H.; Titze, A. \& Tanaka, H. 2005: Male labial gland secretions and mitochondrial DNA markers support species status of B. cryptarum and B. magnus (Hymenoptera, Apidae). - Insectes Sociaux 52: 45-54.

Bryson, H. C. \& Haney, S. L. 2006: Final Report Franklin's Bumble Bee Inventory in the Southern Cascades Oregon. Available from www.fs.fed.us/r6/sfpnw/issssp/documents/inventories/inv-rpt-iihybofr-med-southerncascades-inventory-2006-10.pdf

Buckell, E. R. 1951: Records of bees from British Columbia. - Proceedings Entomological Society of British Columbia 47: 7-24.

Cameron, S. A.; Hines, H. M. \& Williams, P. 2007: A comprehensive phylogeny of the bumble bees (Bombus). - Biological Journal of the Linnean Society 91: 161-188.

Cha, S. Y.; Yoon, H. J.; Lee, H. E. M.; Yoon, M. H.; Hwang, J. S.; Bin, B. R.; Han, Y. S. \& Kim, I. 2007: The complete nucleotide sequence and gene organization of the mitochondrial genome of the bumblebee, Bombus ignitus (Hymenoptera, Apidae). - Gene 392: 206-220.

Colla, S. \& Packer, L. 2008: Evidence for decline in eastern North American bumblebees (Hymenoptera: Apidae), with special focus on Bombus affinis Cresson. - Biodivers. and Conserv. 17: 1379-1391.

FrankLin, H. J. 1913: The Bombidae of the New World. - Transactions of the American Entomological Society 38 (1912): 177-486.

Hillis, D. M. 1994: Homology in molecular biology. - In: Homology the hierarchical basis of comparative biology. Edited by B. H. Hall. - Academic Press, London New York: 197-227.

Новвs, G. A. 1968: Ecology of species of Bombus (Hymenoptera: Apidae) in Southern Alberta VII. Subgenus Bombus. - Canadian Entomologist 100: 156-164.

Huelsenbeck, J. P. \& Ronquist, F. 2001: Mr Bayes: Bayesian inference of phylogeny. - Bioinformatics 17: 754-755.

Kawakita, A.; Sota, T.; Ito, M.; Ascher, J. S.; Tanaka, H.; Kato, M. \& Roubik, D. W. 2004: Phylogeny, historical biogeography and character evolution in bumble bees (Bombus: Apidae) based on simultaneous analysis of three nuclear gene sequences. - Molecular Phylogenetics and Evolution 31: 799-804.

KRÜGER, E. 1939: Die Hummeln und Schmarotzerhummeln von Sylt und dem benachbarten Festland. - Schriften des Naturwissenschaftlichen Vereins Schleswig-Holstein 23: 28-123. 
KRÜGER, E. 1954: Phänoanalytische Studien an einigen Arten der Untergattung Terrestribombus O. Vogt (Hymenoptera, Bombidae). II. Teil. - Tijdschrift voor Entomologie 97: 263-298.

Kumar, S.; Nei, M.; Dudley, J. \& Tamura, K. 2008. MEGA: A biologist-centric software for evolutionary analysis of DNA and protein sequences. - Briefings in Bioinformatics 9: 299-306.

Lefébure, T.; Douady, C. J.; Gouy, M. \& Gibert, J. 2006: Relationship between morphological taxonomy and molecular divergence within Crustaceae: proposal of a molecular threshold to help species delimitation. - Molecular Phylogenetics and Evolution 40: 435-447.

Milliron, H. E. 1971: A monograph of the western hemisphere bumblebees (Hymenoptera: Apidae; Bombinae). I. The genera Bombus and Megabombus Subgenus Bombias. - Memoirs of the Entomological Society of Canada 82: 1-80.

Moore, W. S. 1995: Inferring phylogenies from mtDNA variation: Mitochondrial-gene trees versus nucleargene trees. - Evolution 94: 718-726.

Munroe, E. 1956: Canada as an Environment for Insect life. - The Canadian Entomologist 88: 372-476. (Fig. 26 Map Forest Classification of Canada).

Pedersen, B. V. 1996: A phylogenetic analysis of cuckoo bumblebees (Psithyrus, Lepelletier) and bumblebees (Bombus; LATREILLE) inferred from sequences of the mitochondrial gene cytochrome oxidase I. - Molecular Phylogenetics and Evolution 5: 289-297.

Pedersen, B. V. 2002: European bumblebees (Hymenoptera: Bombini) - phylogenetic relationships inferred from DNA sequences. - Insect Systematics \& Evolution 33: 361-386.

Plowright, R. C. \& Stephen, W. P. 1980: The taxonomic status of Bombus franklini (Hymenoptera: Apidae). - Canadian Entomologist 112: 475-479.

Poole, R. W. 1996: Nomina insecta nearctica, a checklist of the insects of North America. - Rockville, Maryland.

PosadA, D. 2008: jModelTest: phylogenetic model averaging. - Molecular Biology and Evolution 25: 1253-1256.

Rasmont, P. 1984: Les Bourdons du genre Bombus Latreille sensu stricto en Europe Occidentale et Centrale (Hymenoptera, Apidae). - Spixiana 7: 135-160.

Scholl, A. \& Оввеснт, E. 1983: Enzymelektrophoretische Untersuchungen zur Artabgrenzung im Bombus lucorum-Komplex (Apidae, Bombini). - Apidologie 14: 65-78.

Scholl, A.; Oвrecht, E. \& Owen, R. E. 1990: The genetic relationship between Bombus moderatus Cresson and the Bombus lucorum auct species complex (Hymenoptera: Apidae). - Canadian Journal of Zoology 68: 2264-2268.

Scholl, A.; Thorp, R. W. \& Oвrecht, E. 1992: The genetic relationship between B. franklini (Frison) and other taxa of the subgenus Bombus s. str. (Hymenoptera: Apidae). - Pan-Pacific Entomologist 68: 46-51.

Simon, C.; Frati, F.; Beckenbach, A.; Crespie, B.; Liu, H. \& Flook, P. 1994: Evolution, weighting and phylogenetic utility of mitochondrial gene sequences and a compilation of conserved polymerase chain reaction primers. - Annals Entomology Society America 87: 651-701.

Stephen, W. P. 1957: Bumble bees of Western America (Hymenoptera: Apoideae). - Oregon State Coll. Agriculture Experimental Station Technical Bulletin 40: 1-163.

Tamura, K. \& NeI, M. 1993: Estimation of the number of nucleotide substitutions in the control region of mitochondrial DNA in humans and chimpanzees. - Molecular Biology and Evolution 10: 512-526.

Tamura, K.; Dudley, L.; Nei, M. \& Kumar, S. 2007: Mega 4.0: Molecular Evolutionary Genetics Analysis (Mega) software version 4.0. - Molecular Biology and Evolution 24: 1596-1599.

Thorp, R. W.; Horning Jr., D. S. \& Dunning, L. L. 1983: Bumble bees and cuckoo bumble bees of California (Hymenoptera: Apidae). - Bulletin California Insect Survey 29: 1-79.

Thorp, R. W. 2005: Species Profile: Bombus franklini. - In: Red list of pollinator insects of North America. Edited by M. D. Shepherd, D. M. Vaughan \& S. H. Black, CD-ROM Version. - Portland, OR, The Xerces Society for Invertebrate Conservation. Available from www.xerces.org/franklins-bumble-bee. 
Thorp, R. W. \& Shepherd, M. D. 2005: Profile: Subgenus Bombus. - In: Red list of pollinator insects of North America. Edited by M. D. Shepherd, D. M. Vaughan \& S. H. Black. CD-ROM Version. - Portland, OR, The Xerces Society for Invertebrate Conservation.

Williams, P. H. 1998: An annotated checklist of bumble bees with an analysis of patterns of description (Hymenoptera: Apidae, Bombini). - Bulletin of the British Museum Natural History Entomology 67: 79-152.

WiLLiams, P. H. 2009: www.nhm.ac.uk/research-curation/projects/bombus/bo.html\#terricola.

\section{Authors' addresses:}

Prof. Dr. Andreas Bertsch

Department of Biology, Philipps-University Marburg

Karl-von-Frisch Straße 8

35032 Marburg, Germany

e-mail: bertsch@staff.uni-marburg.de

Prof. Dr. Martin Hrabé de Angelis and Dr. Gerhard K. H. Przemeck

Institute of Experimental Genetics, Helmholtz-Zentrum München

Ingoldstädter Landstraße 1

85764 Neuherberg, Germany

e-mail: hrabe@helmholtz-muenchen.de and przemeck@helmholtz-muenchen.de
Subject editor:

Prof. Dr. H. H. Dathe 